\title{
Association of Serum and Cervical Tissue Levels of Organochlorine Pesticides with Cervical Cancer in Women of East Delhi: A Case Control Pilot Study
}

\author{
Varsha Priyadarshini ${ }^{1}$, Alpana Singh ${ }^{2}$, Basu Dev Banerjee ${ }^{3}$, Gita Radhakrishnan $^{4}$
}

\begin{abstract}
Aim and objectives: Organochlorine pesticides (OCPs), known to have estrogenic activity, have been implicated in pathogenesis of reproductive tract cancers. Our study was aimed at understanding the role of OCPs in cervical cancer.

Materials and methods: Approximately $3 \mathrm{~mL}$ of blood and $1 \mathrm{~g}$ of cervical tissue was taken from 30 cervical cancer patients and 30 controls and subjected to OCP analysis. Blood and tissue levels of OCPs were compared between cases and controls and correlation was assessed between OCP levels in blood and cervical tissue in each subject.

Results: Blood levels of endosulfan-I (1.72 vs $1.23 \mathrm{ppb}, p=0.001)$, ppDDD (1.66 vs $0.002 \mathrm{ppb}, p=0.001)$ and cervical tissue levels of $\beta \mathrm{HCH}$ (4.23 vs $1.38 \mathrm{ppb}, p=0.000$ ), heptachlor ( $3.54 \mathrm{vs} 1.87 \mathrm{ppb}, p=0.008)$ and endosulfan-II ( $1.20 \mathrm{vs} 0.66 \mathrm{ppb}, p=0.000)$ were significantly raised in cervical cancer patients compared to controls. No correlation was found between OCP levels in blood and cervical tissue in either case or control. Conclusion: OCP exposure may be associated with increased risk of cervical cancer. Also, there does not seem to be any correlation between blood and cervical tissue levels of pesticides.

Keywords: Bioaccumulation, Cervical cancer, Organochlorine pesticides.

Journal of South Asian Federation of Obstetrics and Gynaecology (2019): 10.5005/jp-journals-10006-1690
\end{abstract}

\section{INTRODUCTION}

Cervical cancer is the 4 th most common cause of cancer in the world ${ }^{1}$ and the second most common cause of cancer amongst Indian women, ${ }^{2}$ accounting for significant mortality and morbidity in this group. Women aged between 21 years and 67 years are especially prone to this disease. ${ }^{3}$ Human papillomavirus infection is known to be a classic risk factor for cervical cancer. ${ }^{4,5}$ However, recent studies have illustrated that HPV infection, although necessary, is not sufficient for cervical cancer pathogenesis and further research in the study of the cofactors involved has been suggested. 6

One of the proposed cofactors in cervical cancer pathogenesis are organochlorine pesticides (OCP). Organochlorines were first marketed during World War 2 to deal with the problems of pest infestation. ${ }^{7,8}$ Crop yields increased and so did their incessant use. Later it was found that these "miraculous compounds" harbor a grave but silent danger within. They exhibited a property called bioaccumulation which is a process by which chemicals progressively accumulate as one goes higher up the food chain, thus making man who sits at the top of the chain, significantly exposed to these compounds. ${ }^{9}$

Subsequently these chemicals were banned across most of the developed nations in Stockholm Convention 2004. However, despite the ban, a sizeable proportion of world's population still uses organochlorines like DDT on and off label, especially in underdeveloped and developing nations like India. ${ }^{10}$

It is well known that the prevalence of various cancers have increased in past few decades since the introduction of these compounds in the market. ${ }^{7}$ Organochlorines have been shown to be associated with cancers of various organs of human body like breast, prostate, testicular and reproductive tract cancers. ${ }^{11-14}$
1,2,4 Department of Obstetrics and Gynaecology, University College of Medical Sciences and Guru Teg Bahadur Hospital, New Delhi, India

${ }^{3}$ Department of Biochemistry, University College of Medical Sciences and Guru Teg Bahadur Hospital, New Delhi, India

Corresponding Author: Alpana Singh, Department of Obstetrics and Gynaecology, University College of Medical Sciences and Guru Teg Bahadur Hospital, New Delhi, India, Phone: +91 7042109290, e-mail: dralpanasingh@gmail.com

How to cite this article: Priyadarshini V, Singh A, Banerjee BD, et al. Association of Serum and Cervical Tissue Levels of Organochlorine Pesticides with Cervical Cancer in Women of East Delhi: A Case Control Pilot Study. J South Asian Feder Obst Gynae 2019;11(3):190-193.

Source of support: It was funded by ICMR, Delhi and IMRG of UCMS, Delhi Conflict of interest: None

However, literature is scarce with respect to the role of OCPs in cervical cancer. However Fleming et al., in a prospective study, found that the incidence of cervical cancer increased significantly amongst the pesticide applicators of Florida. ${ }^{15}$ Similarly Mathur et al. measured OCP levels in blood of women with reproductive tract cancers and found them to be significantly higher than controls. ${ }^{13}$

The aim of this study is to assess the role of organochlorine pesticides in cervical cancer by measuring the serum and cervical tissue levels of these compounds and also find a correlation between the two, if any.

\section{Materials and Methods}

The study was carried out in a tertiary care hospital of East Delhi. A total of 30 women with histopathologically proven carcinoma cervix was taken as cases and 30 age matched controls were chosen from women undergoing hysterectomy for benign conditions. Informed 
consent was taken from each subject. Patient's sociodemographic data was recorded, history and general physical examination was done. Clearance was taken from Institutional Ethics CommitteeHuman Research (IEC-HR) of our institution. (vide their approval number "nil" dated October 30, 2014).

Approximately $3 \mathrm{~mL}$ of blood sample was collected in EDTA vial from each subject. Punch biopsy of cervical tissue of patients with suspected cervical cancer was taken. Alternatively, wedge biopsy of the malignant part of cervix was taken from the hysterectomy specimen of patients undergoing Wertheim's/radical hysterectomy for operable cervical cancer. Also, wedge biopsy of cervical tissue was taken from the cervix in the hysterectomy specimen of controls. The tissue specimens were stored in phospho buffered saline at $4^{\circ} \mathrm{C}$.

\section{Organochlorine Pesticides Analysis}

- Extraction and cleanup of OCP residues from blood and tissue samplesPesticide extraction was done using standard method described by Mustafa et al. ${ }^{16}$

- Quantification of levels of OCPs

Samples were analyzed by Perkin Elmer gas chromatograph (Clarus 500) equipped with 63Ni electron capture detector (ECD) under standardized operating conditions of the laboratory.

Table 1: Comparison of OCP levels in serum of cases and controls

\begin{tabular}{llll}
\hline $\begin{array}{l}\text { Organochlorine } \\
\text { pesticides }\end{array}$ & $\begin{array}{l}\text { Group I cases } \\
(n=30) \text { median } \\
(I Q R)\end{array}$ & $\begin{array}{l}\text { Group I controls } \\
(n=30) \text { median } \\
(I Q R)\end{array}$ & p value \\
\hline aHCH & $3.36(5.78)$ & $3.06(6.90)$ & 0.175 \\
$\beta \mathrm{HCH}$ & $4.53(7.45)$ & $1.60(11.51)$ & 0.273 \\
$\gamma \mathrm{HCH}$ & $1.84(7.35)$ & $2.29(3.97)$ & 0.923 \\
$\delta \mathrm{HCH}$ & $3.95(5.39)$ & $1.60(6.94)$ & 0.064 \\
$\mathrm{Heptachlor}$ & $0.55(2.22)$ & $0.99(2.56)$ & 0.329 \\
DDT & $2.90(9.63)$ & $2.70(4.68)$ & 0.513 \\
Endosulfan I & $1.72(6.42)$ & $1.23(8.95)$ & $0.001^{*}$ \\
Dieldrin & $0.45(3.35)$ & $0.002(2.41)$ & 0.651 \\
Endosulfan II & $1.33(4.34)$ & $1.66(4.68)$ & 0.599 \\
ppDDD & $1.66(1.95)$ & $0.002(1.93)$ & $0.001^{*}$ \\
\hline
\end{tabular}

${ }^{*} p<0.05$ significant

\section{Statistical Analysis}

The OCP levels in blood and cervical tissue were compared with the help of unpaired Student's $t$ test. Spearman correlation was used to compare OCP levels between blood and cervical tissue for each subject.

\section{Results}

Residues of all pesticides like isomers of $\mathrm{HCH}, \mathrm{DDT}, \mathrm{DDD}$, heptachlor, endosulfan I and II and dieldrin were detected in serum and cervical tissue of both the cases and controls. However the levels of endosulfan I (1.72 vs $2.23 \mathrm{ppb}, p=0.001)$ and ppDDD (1.66 vs $0.002 \mathrm{ppb}, p=0.001$ ) were significantly higher in serum of cases compared to controls (Table 1 and Fig. 1). Similarly the levels of $\beta \mathrm{HCH}$ (4.23 vs $1.38 \mathrm{ppb}, p=0.000$ ), heptachlor (3.54 vs $1.87 \mathrm{ppb}$, $p=0.008)$ and endosulfan-II (1.20 vs $0.66 \mathrm{ppb}, p=0.000)$ were significantly higher in cervical tissue samples of cases compared to controls (Table 2 and Fig. 2).

In order to see whether serum levels of OCPs are representative of their corresponding cervical tissue levels, we made a correlation between the two levels in each subject (case and control using Spearman correlation). We found no correlation between serum and cervical tissue levels of OCPs in the cases or controls for any of the pesticides (Tables 3 and 4).

\section{Discussion}

Cervical cancer has a sizeable burden on the health infrastructure of the world owing to considerable mortality and morbidity associated with the disease. ${ }^{1,17}$ Organochlorine pesticides have recently been proposed to be involved in the pathogenesis of carcinoma cervix.

India ranks 12 th in the world and 2 nd in Asia in terms of pesticide production. ${ }^{18}$ OCPs have high bioaccumulative potential and strong lipophilicity such that they are still detected in the western population where strong regulatory measures have been taken to curb their production almost 2 decades back. ${ }^{7}$ In India the poor regulatory and safety measure taken during pesticide production and use are the main problem behind its accumulation in the population. ${ }^{19}$

In the present study, 30 cases of cervical cancer were enrolled, 30 healthy and matched controls who underwent hysterectomy for benign causes were also enlisted for the study.

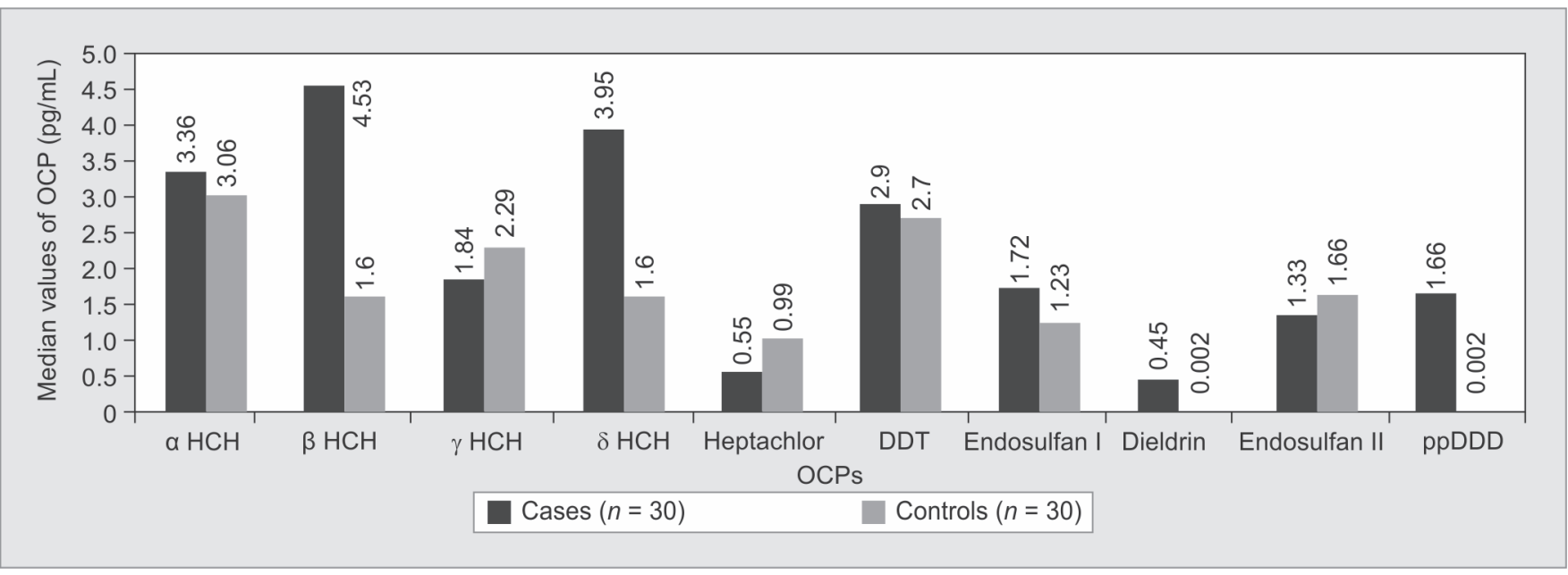

Fig. 1: Comparison of OCP levels in blood of cases and controls 
The age of cervical cancer patients in our study ranged from 28 years to 68 years. Mean age of the group was 50.9 years. Majority of the women in the cervical cancer group belonged to 40-60-year age group. The controls also had a similar age distribution. The mean age of this group was 49.3 years.

The women of the two study groups were similar to each other in sociodemographic parameters. Majority of the women in both groups belonged to 40-60-year age group and had 3 or more children ( $86 \%$ vs $80 \%)$. The first age at intercourse was comparable in both study groups with 19.2 years in case and 19.3 years in control group. We didn't find any woman practicing high risk sexual behavior in any of the study groups or HIV positive patients. As the subjects mostly came from the same geographical catchment area, i.e., East Delhi, it was advantageous to our study as they had similar environmental exposure to pesticides through water and food resources. Women with occupational exposure to pesticides were excluded from the study.

We estimated pesticide residues in blood and cervical tissue samples of both cases and controls. Residues of 10 OCPs namely $\mathrm{aHCH}, \beta \mathrm{HCH}, \gamma \mathrm{HCH}, \delta \mathrm{HCH}, \mathrm{DDT}$, heptachlor, ppDDD, dieldrin, endosulfan I and endosulfan II were detected in blood and cervical tissue samples of both the study groups. It is important to note that some of these pesticides like $\mathrm{HCH}$ and its isomers, heptachlor and dieldrin have been banned all over the world as per rules laid

Table 2: Comparison of OCP levels in cervical tissue of cases and controls

\begin{tabular}{llll}
\hline $\begin{array}{l}\text { Organochlorine } \\
\text { pesticides }\end{array}$ & $\begin{array}{l}\text { Group / cases } \\
(n=30) \text { median } \\
(I Q R)\end{array}$ & $\begin{array}{l}\text { Group / controls } \\
(n=30) \text { median } \\
(I Q R)\end{array}$ & p value \\
\hline $\mathrm{aHCH}$ & $1.51(4.62)$ & $1.65(4.24)$ & 0.403 \\
$\beta \mathrm{HCH}$ & $4.23(7.64)$ & $1.38(4.20)$ & $0.000^{*}$ \\
YHCH & $2.45(14)$ & $2.54(5.61)$ & 0.537 \\
$\delta \mathrm{HCH}$ & $3.40(6.33)$ & $2.72(4.34)$ & 0.058 \\
$\mathrm{Heptachlor}$ & $3.54(4.77)$ & $1.87(4.29)$ & $0.008^{*}$ \\
DDT & $1.70(2.98)$ & $1.62(2.26)$ & 0.105 \\
Endosulfan I & $1.07(2.74)$ & $0.94(1.63)$ & 0.383 \\
Dieldrin & $1.94(3.61)$ & $1.56(3.67)$ & 0.117 \\
Endosulfan II & $1.20(1.80)$ & $0.66(0.99)$ & $0.000^{*}$ \\
ppDDD & $1.34(2.23)$ & $1.11(2.90)$ & 0.064 \\
\hline
\end{tabular}

${ }^{*} p<0.05$ significant down during the Stockholm Convention in 2004. On the other hand, pesticides like DDT and endosulfan have been banned in the west but are still used in India.

The blood levels of endosulfan I and ppDDD and cervical tissue levels of $\beta \mathrm{HCH}$, heptachlor and endosulfan II were significantly raised in patients of cervical cancer compared to controls. Our findings were consistent with the study conducted by Mathur et al. who found significant higher levels of DDD and heptachlor in blood in cervical cancer patients amongst other reproductive tract cancers. ${ }^{13}$

Sharma et al. in a case control study at GTB Hospital, Delhi in 2014 found significant higher levels of endosulfan, $\mathrm{BHCH}$ and DDE in ovarian cancer patients. ${ }^{12}$ Tyagi et al. similarly reported high levels of $\beta \mathrm{HCH}$, DDE and DDD in women of preterm labor in another case control study in Delhi. ${ }^{19}$ Kaushik et al. reported high levels of $\mathrm{BHCH}$ and DDT in the river Yamuna, the major source of water in Delhi. ${ }^{20}$ Similarly Pandey et al. observed high levels of endosulfan and DDT in the surface sediments of Yamuna river. ${ }^{21}$ Another study by Central Food Technological Research Institute detected high levels of DDT and $3 \mathrm{HCH}$ in $30 \%$ of 20 random wheat samples. ${ }^{22}$ This explains the high levels of $\beta \mathrm{HCH}, \mathrm{DDD}$ (metabolite of DDT) and endosulfan in our population.

Almost all studies in the past with respect to role of organochlorines in various cancers of human body have been done by estimating the serum levels of these compounds. Our data suggests that the OCP levels in the serum may not be representative of tissue levels. This could be due to higher tissue affinity of some compounds compared to other. Hence it is important to measure the organochlorine levels in the corresponding tissue as well, in order to understand their local effect in the tissue microenvironment.

\section{Strength of study}

Our study is a pilot study that aims to pioneer in finding the role of organochlorine pesticides in cervical cancer. Also, unlike other studies that have estimated their values only in serum in order to find an association between OCP with various cancers, we have additionally measured OCP levels in tissue as well to understand more accurately what spectrum of OCPs are involved in cervical cancer.

\section{Limitations}

Due to the limited funds available, we could not assess correlation between HPV infection and OCP exposure since ours was a pilot study and the sample size was small.

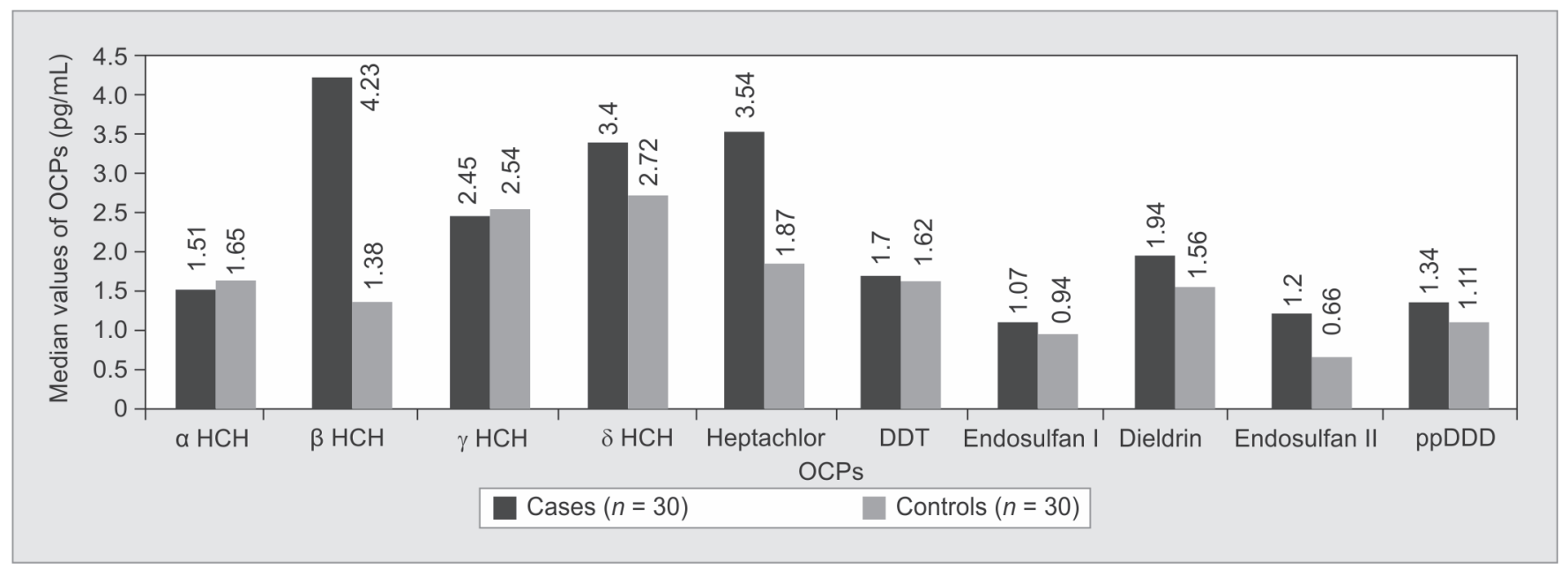

Fig. 2: Comparison of OCP levels in cervical tissue of cases and controls 
Table 3: Comparison of serum and cervical tissue levels of OCPs in cases

\begin{tabular}{lcl}
\hline Pesticides $(n=30)$ & $\begin{array}{c}\text { Spearman correlation } \\
\text { coefficient }\end{array}$ & p value \\
\hline aHCH & 0.191 & 0.312 \\
$\beta \mathrm{HCH}$ & -0.150 & 0.428 \\
$\gamma \mathrm{HCH}$ & 0.204 & 0.279 \\
$\delta \mathrm{HCH}$ & -0.107 & 0.575 \\
Heptachlor & 0.384 & 0.420 \\
DDT & 0.097 & 0.611 \\
Endosulfan I & -0.069 & 0.715 \\
Dieldrin & 0.109 & 0.566 \\
Endosulfan II & -0.227 & 0.227 \\
ppDDD & 0.107 & 0.572 \\
\hline
\end{tabular}

$p<0.05$ significant

\section{Conclusion}

Our data suggests that the North Indian population has significant exposure to OCPs like HCH, DDT, heptachlor, dieldrin and endosulfan with special reference to population of East Delhi. This exposure could be from local water and food resources. Exposure to pesticides particularly $\mathrm{\beta HCH}$, heptachlor, endosulfan (I and II) and ppDDD may be associated with a higher risk for cervical cancer, however this needs to be substantiated with similar research on a larger population. Also, the serum levels of pesticides may not be representative of the corresponding cervical tissue levels and hence both need to be studied in order to understand the systemic as well as local effects of these compounds. We recommend similar studies to be carried out in future on a larger population with an additional correlation with HPV infection.

\section{References}

1. Cervical cancer statistics. Available from: http://www.wcrf.org/int/ cancer-facts-figures/data-specific-cancers/cervical-cancer-statistics, accessed on 2nd April 2016.

2. Pandey V, Purohit MR, Dhand PL. Immunocytochemical staining of cervical smears - A comparative study with routine cytology for confirmation of precancerous and cancerous lesions of cervix. Int J Med Res Rev 2016;4:3-11.

3. Karthigeyan K. Cervical cancer in India and HPV vaccination. Indian J Med Paediatr Oncol 2012;33(1):7-12. DOI: 10.4103/0971-5851.96961.

4. Son J, Park JW, Lambert PF, et al. Requirement of estrogen receptor alpha DNA-binding domain for HPV oncogene-induced cervical carcinogenesis in mice. Carcinogenesis 2014;35(2):489-496. DOI: 10.1093/carcin/bgt350.

5. zur Hausen H. Papillomaviruses and cancer: from basic studies to clinical application. Nat Rev Cancer 2002;2:342-350. DOI: 10.1038/ nrc798.

6. Roura E, Travier N, Waterboer T, et al. The Influence of Hormonal Factors on the Risk of Developing Cervical Cancer and Pre-Cancer: Results from the EPIC Cohort. PLoS One 2016;11(1):e0147029. DOI: 10.1371/journal.pone.0147029.

7. Miller WR, Sharpe RM. Environmental oestrogens and human reproductive cancers. Endocrine Relat Cancer 1998;5:69-96. DOI: 10.1677/erc.0.0050069.

8. Cooper J, Dobson H. The benefits of pesticides to mankind and the environment. Crop Prot 2007;26:1337-1348. DOI: 10.1016/ j.cropro.2007.03.022.
Table 4: Comparison of serum and cervical tissue OCP levels in controls

\begin{tabular}{lcl}
\hline Pesticides $(n=30)$ & $\begin{array}{l}\text { Spearman correlation } \\
\text { coefficient }\end{array}$ & p value \\
\hline aHCH & 0.039 & 0.840 \\
$\beta H C H$ & 0.095 & 0.617 \\
YHCH & -0.317 & 0.087 \\
SHCH & 0.033 & 0.864 \\
Heptachlor & 0.223 & 0.237 \\
DDT & -0.235 & 0.211 \\
Endosulfan I & -0.054 & 0.778 \\
Dieldrin & -0.165 & 0.383 \\
Endosulfan II & 0.259 & 0.166 \\
ppDDD & 0.060 & 0.752 \\
\hline
\end{tabular}

$p<0.05$ significant

9. Mnif W, Hassine Al, Bouaziz A, et al. Effect of endocrine disruptor pesticides: a review. Int J Environ Res Public Health 2011;8(6): 2265-2303. DOI: 10.3390/ijerph8062265.

10. List of pesticides which are banned, refused registration and restricted in use. Available from: www.cibrc.nic.in/ibr2012.doc, accessed on 5th April 2016.

11. Xu X, Dailey AB, Talbott EO, et al. Associations of serum concentrations of organochlorine pesticides with breast cancer and prostate cancer in U.S. adults. Environ Health Perspect 2010;118(1):60-66. DOI: 10.1289/ehp.0900919.

12. Sharma T, Banerjee BD, Mazumdar D, et al. Association of organochlorine pesticides and risk of epithelial ovarian cancer: $\mathrm{A}$ case control study. J Reprod Health Med 2015;1:76-82. DOI: 10.1016/ j.jrhm.2015.01.006.

13. Mathur V, John PJ, Soni I, et al. Blood levels of organochlorine pesticide residues and risk of reproductive tract cancer among women from Jaipur, India. Adv Exp Med Biol 2008;617:387-394. DOI: 10.1007/9780-387-69080-3_37.

14. Hardell L, van Bavel B, Lindström $G$, et al. Adipose tissue concentrations of $p, p^{\prime}-D D E$ and the risk for endometrial cancer. Gynecol Oncol 2004;95(3):706-711. DOI: 10.1016/j.ygyno.2004.08. 022.

15. Fleming LE, Bean JA, Rudolph M, et al. Cancer incidence in a cohort of licensed pesticide applicators in Florida. J Occup Environ Med 1999;41(4):279-288. DOI: 10.1097/00043764-199904000-00010.

16. Mustafa MD, Banerjee BD, Ahmed RS, et al. Gene-environment interaction in preterm delivery with special reference to Organochlorine pesticides. Mol Hum Reprod 2013;19(1):35-42. DOI: 10.1093/molehr/gas039.

17. What are the key statistics about cervical cancer? Available from: http://www.cancer.org/cancer/cervicalcancer/detailedguide/ cervical-cancer-key-statistics, accessed on 5th March 2016.

18. Mathur SC. Future of Indian pesticides industry in next millennium. Pesticide Information 2010;24(4):9-23.

19. Tyagi V, Garg N, Mustafa MD, et al. Organochlorine pesticide levels in maternal blood and placental tissue with reference to preterm birth: a recent trend in North Indian population. Environ Monit Assess 2015;187(7):471. DOI: 10.1007/s10661-015-4369-x.

20. Kaushik CP, Sharma HR, Jain $S$, et al. Pesticide residues in river Yamuna and its canals in Haryana and Delhi, India. Environ Monit Assess 2008;144(1-3):329-340. DOI: 10.1007/s10661-007-9996-4.

21. Pandey P, Khillare PS, Kumar K. Assessment of organochlorine pesticide residues in the surface sediments of river Yamuna in Delhi, India. J Environ Protec 2011;2:511-524. DOI: 10.4236/jep.2011.25059.

22. Agarwal A. Contaminated wheat. Down Earth 2000;31:22. 